\title{
Genotyping analysis of the Pax9 Gene in patients with
}

\section{maxillary canine impaction [version 1; peer review: 2}

\section{approved]}

\author{
Evy Eida Vitria1, Iwan Tofani', Lindawati Kusdhany², Endang Winiati Bachtiar(i)3 \\ ${ }^{1}$ Departement of Oral \& Maxillofacial Surgery, Faculty of Dentistry,, Universitas Indonesia, Jakarta, 10430, Indonesia \\ ${ }^{2}$ Departement of Prosthodontic, Faculty of Dentistry, Universitas Indonesia, Jakarta, 10430, Indonesia \\ ${ }^{3}$ Department of Oral Biology, Oral Science Research Center, Faculty of Dentistry Universitas Indonesia, Jakarta, 10430, Indonesia
}

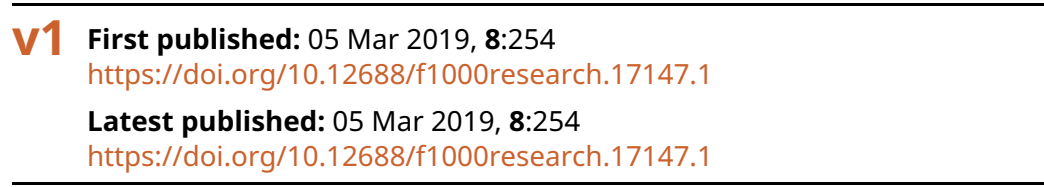

\section{Abstract}

Background: Paired-box gene 9 (PAX9) mutation is potentially associated with impaction in some patient populations. Here, we analyzed the relationship between $P A X 9$ polymorphism and the occurrence of maxillary canine impaction.

Methods: Patients with and without maxillary canine impaction were selected based on specific inclusion criteria, and samples of genomic DNA were obtained from a buccal mucosa swab. DNA was amplified by polymerase chain reaction and sequenced for further bioinformatics analysis to identify single nucleotide polymorphism (SNP) genotypes. Genotype and allele counting was performed in both case and control groups prior to conducting statistical analysis. Results: Four SNPs were identified in patients with maxillary canine impaction, with relative confidence determined based on chromatogram-peak assessment. All SNPS were located in exon 3 of PAX9 and in the region sequenced by the primer pair $-197 \mathrm{Fex} 3$ and +28Rex3. Three of the SNPs (rs375436662, rs12881240, and rs4904210) were reported previously and are annotated in NCBI (dbSNP version 150), whereas another SNP mapped to chromosome 14 has not been reported. Patients with a CC genotype at SNP 3 [odds ratio (OR): 2.61 vs. TT; 1.28 vs. CT] and a CC genotype at SNP 4 [OR: 0.71 vs. GG; 0.79 vs. $\mathrm{CG}$ ] were more likely to have maxillary canine impaction.

Conclusions: These results demonstrated that the presence of SNPs 3 and 4 is associated with increased likelihood of suffering from maxillary canine impaction.

Keywords

Canine impaction, PAX9 gene, PCR, sequencing DNA, SNPs, Genotype

\section{Open Peer Review Approval Status 2 \\ version 1 \\ 05 Mar 2019

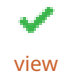 \\ $\checkmark$
view \\ 1. Heni Susilowati (ID), Gadjah Mada University, \\ Yogyakarta, Indonesia \\ 2. Fathilah Binti Abdul Razak (D), University of \\ Malaya, Kuala Lumpur, Malaysia \\ Any reports and responses or comments on the article can be found at the end of the article.}


Corresponding author: Endang Winiati Bachtiar (endangwiniati08@gmail.com)

Author roles: Vitria EE: Conceptualization, Data Curation, Investigation, Project Administration, Resources, Writing - Original Draft Preparation; Tofani I: Conceptualization, Supervision, Validation; Kusdhany L: Conceptualization, Formal Analysis, Supervision, Validation; Bachtiar EW: Conceptualization, Methodology, Supervision, Validation

Competing interests: No competing interests were disclosed.

Grant information: The author(s) declared that no grants were involved in supporting this work.

Copyright: (c) 2019 Vitria EE et al. This is an open access article distributed under the terms of the Creative Commons Attribution License, which permits unrestricted use, distribution, and reproduction in any medium, provided the original work is properly cited.

How to cite this article: Vitria EE, Tofani I, Kusdhany L and Bachtiar EW. Genotyping analysis of the Pax9 Gene in patients with maxillary canine impaction [version 1; peer review: 2 approved] F1000Research 2019, 8:254

https://doi.org/10.12688/f1000research.17147.1

First published: 05 Mar 2019, 8:254 https://doi.org/10.12688/f1000research.17147.1 


\section{Introduction}

Maxillary canine teeth are the second most common targets of impaction after the third molars ${ }^{1}$. An impacted maxillary canine occurs in $1 \%$ to $3 \%$ of the general population and is twice as common in females as males ${ }^{2,3}$. It is commonly presented in clinics by patients often arriving with an aesthetic-related complaint.

Maxillary canine impaction in the palatal position is possibly caused by genetic factors and often accompanied by dental abnormalities in tooth shape, size, number, and structure. Abnormalities, such as agenesis, oligodontia, and peg-shaped teeth, have a genetic link to the presence of impacted teeth and generally manifest in developmental disorders during growth ${ }^{4-8}$. There is a relationship between malposition of certain teeth, such as palatal canines, and teeth agenesis. Similar to dental agenesis, canine-tooth-position anomalies affect several family members and are considered to be under strong genetic control $^{9-15}$. Paired-box gene 9 (PAX9) is most commonly involved in affecting the odontogenesis process and thought to determine the localization of tooth seeds ${ }^{16}$. In this study, we identified an association between PAX9 genotype and the occurrence of maxillary canine impaction.

\section{Methods}

Patients

Patients were recruited from the Dental Hospital Faculty of Dentistry, Universitas Indonesia, and three different junior high schools in South Jakarta, and the study was conducted through clinical observations from May 2018 to August 2018. Those meeting the inclusion criteria (male or female, 10-25-years old, no systemic disease, and no hereditary disease) were either diagnosed with maxillary canine impaction (group I) or diagnosed as without (group II; control). Diagnosis was based on clinical examinations and radiographic interpretations performed by radiologists and orthodontists who were experts in their fields. Comprehensive clinical data were obtained for 132 patients (see Underlying data ${ }^{17}$ ). All participants gave their written informed consent to participate in this study, which was approved by the Ethics Committee of the Faculty of Dentistry, Universitas Indonesia (No. 07107105/Ethical Approval/ FKGUI/2018).

Polymerase chain reaction (PCR) amplification

Genomic DNA was collected from the buccal mucosa via swabbing and extracted using the Gene Jet whole blood genomic DNA purification kit (Cat. No. K0781; Thermo-Biogen, Karlsruhe, Germany). The area of the buccal mucosa/cheek to be treated was dried with a cotton roll to prevent salivary contamination. Samples from the buccal mucosa were obtained using a cytobrush (\#C0104; Medscan; Cooper Surgical, Trumbull, CT, USA) on the bilateral buccal mucosa, with each side swabbed 10 to 15 times. The cytobrush swab was inserted into a screw-capped Eppendorf tube (Cat. No. SPL-60015; Extragene, Taichung City, Taiwan) containing $200 \mu \mathrm{L}$ of $1 \%$ phosphate-buffered saline. Eppendorf tubes were labeled and stored in a freezer at $-4^{\circ} \mathrm{C}$. DNA concentration was measured using a Qubit Fluorometer 3 (\#Q33216; Invitrogen, Carlsbad, CA, USA) at standard fluorescence wavelengths (excitation/emission: $\sim 480 / 530 \mathrm{~nm}$ ) with Qubits assay reagent (MP423-\#Q32851; Qubit dsDNA HS assay kit; Invitrogen).

We used four sets of primers spanning the $P A X 9$-coding region (exons 2, 3, and 4) (Table 1) and standard PCR procedures for amplification of genomic DNA. PCR was performed using a T100 thermal cycler (No. \#186-1096; Bio-Rad, Hercules, CA, USA) in a total volume of $25 \mu \mathrm{L}$ containing $20 \mu \mathrm{L}$ master mix (MyTag, $12.5 \mu \mathrm{L}$; Primer F, $0.5 \mu \mathrm{L}$; Primer R, $0.5 \mu \mathrm{L}$; and nuclease-free water, $6.5 \mu \mathrm{L}$ ) and $20 \mathrm{ng}$ DNA. Samples were initially heated to $95^{\circ} \mathrm{C}$ for $10 \mathrm{~min}$, followed by 30 cycles of denaturation at $95^{\circ} \mathrm{C}$ for $2 \mathrm{~min}$, primer annealing at the optimal annealing temperature for the $P A X 9$ primer for $1.5 \mathrm{~min}$ (optimal annealing temperature for $P A X 9$ primers were as follows: F1-R1, $60^{\circ} \mathrm{C}$; F2-R2, $64^{\circ} \mathrm{C} ; \mathrm{F} 3-\mathrm{R} 3,60^{\circ} \mathrm{C} ; \mathrm{F} 4-\mathrm{R} 4,56^{\circ} \mathrm{C}$ to $64^{\circ} \mathrm{C}$ ), and extension/elongation at $72^{\circ} \mathrm{C}$ for $2 \mathrm{~min}$ then a final extension at $72^{\circ} \mathrm{C}$ for $15 \mathrm{~min}$.

Table 1. Primer sequences used in this study.

\begin{tabular}{|r|r|l|c|}
\hline Gene & Primers & Sequence & $\begin{array}{c}\text { Size } \\
\text { (base pairs) }\end{array}$ \\
\hline PAX9 & $\begin{array}{r}\text {-58F1ex2 } \\
\text { 357R1ex2 }\end{array}$ & AGGCAGCTGTCCCAAGCAGCG & 410 \\
\hline 109F2ex2 & ATCCGACCGTGTGACATCAGCC & 525 \\
\hline +10R2ex2 & GAGCCCCTACCTTGGTCGGTG & \\
\hline -197Fex3 & GGGAGTAAAACTTCACCAGGC & 550 \\
\hline +28Rex3 & CCACCTGGCCTGACCCTC & \\
\hline -121Fex4 & GGAGAGTAGAAGTCAGAGCATTGCTG & 590 \\
\hline +74Rex4 & GAGACCTGGGAATTGGGGGA & \\
\hline
\end{tabular}

Extracted and adapted from Vastardis et al. (1996) and Nieminen et al. (2001). $(+)$ indicates a sequence of DNA that is in front of the codon where transition begins and (-) the sequence of DNA that is behind the codonF, forward; R, reverse; ex, exon; numeration, nucleotide position in the sequence. 
The PCR products were analyzed by electrophoresis using a 2\% agarose gel (UltraPure Agarose; Cat. No. \#16500500; Thermo Fisher Scientific, Waltham, MA, USA). To make the $2 \%$ agarose gel, $2 \mathrm{~g}$ agarose was added to $100 \mathrm{~mL}$ Tris baseacetate-EDTA (TAE) buffer, followed by the addition of $1 \mu \mathrm{L}$ of GelRed nucleic acid gel stain (Cat. No. \#41003-1; Biotium, Fremont, CA, USA). The wells were loaded with $5 \mu \mathrm{L}$ of sample, with a DNA standard added to one well ; Cat. No. \#SM0241; Thermo Fisher Scientific), and the gel was run at $100 \mathrm{~V}$ for 30 min.. The results of gel electrophoresis were visualized by using UV-transiluminator Gel DocTM 2000 (Cat. No. \#170-8101; Bio-Rad, Hercules, CA, USA).

\section{DNA purification and sequencing}

DNA from the PCR products was purified using an QIAquick PCR purification kit (Cat. No 28106; Qiagen, Hilden, Germany), and purified DNA was sequenced by First-Base Laboratories (Selangor, Malaysia). Sequencing data were edited using BioEdit software (v.7.0.9; Ibis Therapeutics, Carlsbad, CA, USA) and verified using NCBI BLAST (GenBank accession No. NG_0133557.1:5001-25240).

\section{Bioinformatics analysis}

To detect sites containing potential single nucleotide polymorphisms (SNPs), sequencing data were converted to FASTQ format, and chromatogram-peak of each patient DNA sequence was performed as can be seen in the representative data from one sample (Figure 1). Heterozygous SNPs were determined by visually identifying sites containing two overlapping peaks in both the forward and reverse sequences.

For each SNP identified, genotypes across all samples were obtained, annotated, and cross-checked against the NCBI SNP reference database (dbSNP v.150). Both genotype and allele counting were performed before conducting statistical analysis for both the case and control groups.

\section{Statistical analysis}

Statistical analysis of the data was performed using SPSS (v.20.0; SPSS, IBM Corp., Armonk, NY, USA). Analysis was initiated with a quality check of the variables. Analysis of genotype data was conducted using a chi-squared test to compare SNP frequency between patients with maxillary canine impaction and controls. A $\mathrm{P}<0.05$ was considered statistically significant.

\section{Results}

SNP identification

Four SNPs were identified, with all of these located in exon 3 of $P A X 9$ sequenced using primer pair 3 (-197Fex 3 and +28Rex3). Sequencing data for this region were available for 121 of 132 samples, and no SNPs were identified in regions sequenced using the other primer pairs.

Table 2 summarizes the number of SNPs identified. Of the four identified, three were reported previously in exon 3 of PAX9
3286305_116_C9_-197Fex3.ab1 traces

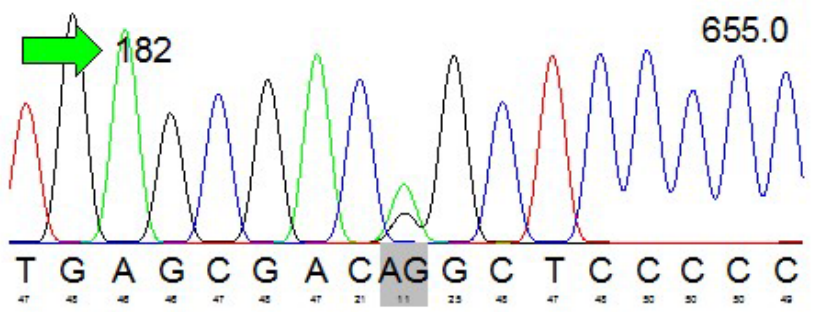

3286304_116_C9_t28Rex3.ab1 traces

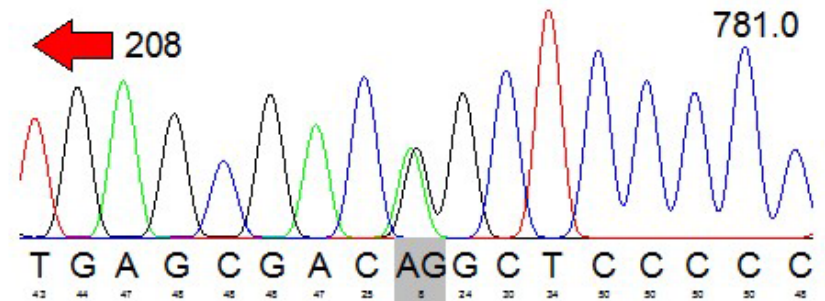

\section{Reference traces}

Forward reference

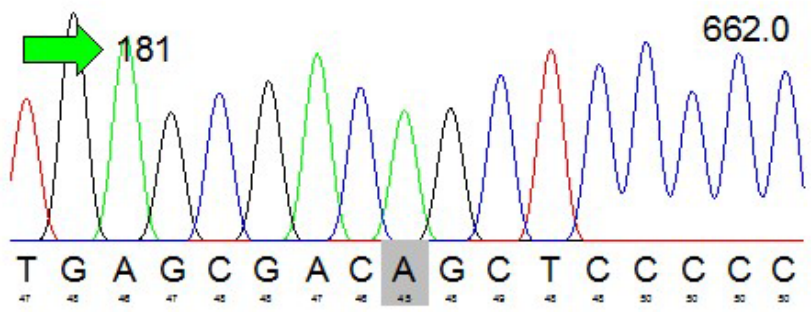

Reverse reference

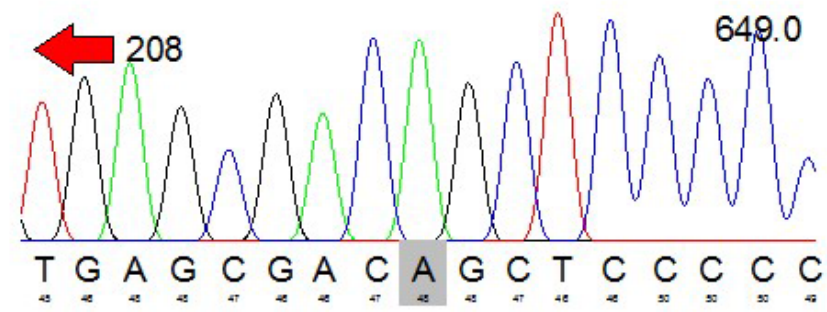

Figure 1. A representative chromatogram analysis of DNA sequencing assessment of data for sample 116 that reveals a heterozygous mutation corresponding to SNP rs3754366. 
and are annotated in NCBI dbSNP (v.150; rs375436662, rs12881240, and rs4904210). The fourth SNP in exon 3 maps to chromosome 14, position $36,666,530$, and has not been previously reported.

Table 3 lists the SNPs identified in this study along with their annotation/reference identification and the location of the nucleotide substitutions. Nucleotide changes included $640 \mathrm{~A}>\mathrm{G}$ in SNP $1,700 \mathrm{C}>\mathrm{T}$ in SNP 2, 717C $>\mathrm{T}$ and $718 \mathrm{G}>\mathrm{C}$ in SNP 3.

\section{Genotype calling}

Genotype assessment was performed for all of the identified SNPs, as well as controls, focusing on counts of homozygous (wild-type) and heterozygous and homozygous (mutant) alleles (Table 4-Table 7).

For SNPs 3 and 4, all genotype and allele variations were observed in both the case and control samples, whereas for SNPs 1 and 2, the homozygous and heterozygous mutants were present in only one of the cases (Table 6 and Table 7).

\section{Statistical analysis}

We then analyzed associations between SNPs 3 and 4, which were present in both case and control samples, and maxillary canine impaction. We verified Hardy-Weinberg equilibrium

\section{Table 2. SNPs identified according to the primers} used.

\begin{tabular}{|r|r|l|c|c|}
\hline Primer pair ID & $\begin{array}{c}\text { Primer in } \\
\text { Samples }\end{array}$ & Gene & Exon & $\begin{array}{c}\text { No of } \\
\text { SNPs } \\
\text { Identified }\end{array}$ \\
\hline Primer pair 1 & 110R2ex2 & PAX9 & 2 & 0 \\
\hline & 109 F2ex2 & & & \\
\hline Primer pair 2 & 357R1ex2 & PAX9 & 2 & 0 \\
\hline & $-58 F 1$ ex2 & & & \\
\hline Primer pair 3 & $--197 F e x 3$ & PAX9 & 3 & 4 \\
\hline & $+28 R e x 3$ & & & \\
\hline Primer pair 4 & -121 Fex4 & PAX9 & 4 & 0 \\
\hline & +74 Rex4 & & & \\
\hline
\end{tabular}

(HWE) for both SNPs in case and control samples (Table 8), with the TT genotype in SNP 3 (rs12881240) showing a higher degree of association with maxillary canine impaction than those with the $\mathrm{CC}$ genotype [odds ratio (OR): 2.61; 95\% Confidence interval (CI): 0.29-23.61] or the CT genotype (OR: 1.28; 95\% CI: 0.57-2.89), although this results was not statistically significant $(\mathrm{P}>0.05)$. This result indicated a similar frequency of recessive and dominant carriers of SNP 3 between case and control samples. Furthermore, no statistical difference in allele frequency was observed between the two groups.

Individuals with the GG genotype in SNP 4 (rs4904210) were less likely to have maxillary canine impaction than those with the CC genotype (OR: $0.71 ; 95 \%$ CI: $0.23-2.16]$ and the CG genotype (OR: 0.79; 95\% CI: 0.31-2.00] (Table 8). Additionally, individuals were less likely to have the $\mathrm{G}$ allele than the C allele (OR: 0.84; 95\% CI: 0.49-1.45]. However, similar to SNP 3, these results were not statistically significant $(\mathrm{P}>0.05)$.

\section{Genotype efficacy for clinical diagnosis}

The use of patient genotype information for clinical assessment represents a possible diagnostic strategy for predicting disease likelihood. Patient characteristics and genotype information were available from 121 of 132 samples, with Table 9 summarizing the clinical information associated with both the case and the control groups.

Stratification of cases with SNP 3 (rs12881240) showed that 21 of 53 males and 24 of 68 females in the case group harbored the CT genotype, whereas only four males and two females harbored the TT genotype, with the difference between males and females in this group not statistically significant $(\mathrm{P}=0.3996)$. Additionally, the OR according to gender was 0.76 (95\% CI: 0.36-1.62) for individuals harboring the CT genotype of SNP 3 (rs12881240) relative to the CC genotype, whereas it was 0.33 (95\% CI: 0.06-1.94) for individuals harboring the TT genotype relative to the $\mathrm{CC}$ genotype.

For SNP 4 (rs4904210), 26 of 53 males and 36 of 68 females in the case group had a CG genotype, whereas 13 males and 13 females had the GG genotype. Additionally, the OR according to gender was 1.02 (95\% CI: $0.43-2.40)$ for individuals harboring the CG genotype of SNP 4 (rs4904210) relative to the CC genotype, whereas it was 0.74 (95\% CI: 0.26-2.07) for individuals harboring the GG genotype relative to the $\mathrm{CC}$ genotype.

Table 3. SNP annotations.

\begin{tabular}{|c|c|c|c|c|c|}
\hline ID & Gene & Chromosome & $\begin{array}{c}\text { chromosome } \\
\text { position }\end{array}$ & rsID & Substitution \\
\hline SNP 1 & PAX9 & 14 & $36,666,470$ & rs375436662 & A $>$ G \\
\hline SNP 2 & PAX9 & 14 & $36,666,530$ & $?$ & C>T \\
\hline SNP 3 & PAX9 & 14 & $36,666,547$ & rs12881240 & C>T \\
\hline SNP 4 & PAX9 & 14 & $36,666,548$ & rs4904210 & G $>$ C \\
\hline
\end{tabular}


Table 4. Genotype analysis of SNP 1 in case and control samples.

\begin{tabular}{|c|c|c|c|c|c|}
\hline & \multicolumn{3}{|c|}{ Genotype Count } & \multicolumn{3}{c|}{ Allele Count } \\
\hline SNP 1/rs375436662 & AA & AG & GG & A & G \\
\hline Maxillary Canine Impaction & 82 & 1 & 0 & 165 & 1 \\
\hline Control & 38 & 0 & 0 & 76 & 0 \\
\hline Total & 120 & 1 & 0 & 241 & 1 \\
\hline
\end{tabular}

Table 5. Genotype analysis of SNP 2 in case and control samples.

\begin{tabular}{|c|c|c|c|c|c|}
\hline & \multicolumn{3}{|c|}{ Genotype Count } & \multicolumn{3}{|c|}{ Allele Count } \\
\hline SNP 2/rs? & CC & CT & TT & C & T \\
\hline Maxillary Canine Impaction & 82 & 1 & 0 & 165 & 1 \\
\hline Control & 38 & 0 & 0 & 76 & 0 \\
\hline Total & 120 & 1 & 0 & 241 & 1 \\
\hline
\end{tabular}

Table 6. Genotype analysis of SNP 3 in case and control samples.

\begin{tabular}{|c|c|c|c|c|c|}
\hline & \multicolumn{3}{|c|}{ Genotype Count } & \multicolumn{3}{|c|}{ Allele Count } \\
\hline SNP 3/rs12881240 & CC & CT & TT & C & T \\
\hline Maxillary Canine Impaction & 46 & 32 & 5 & 124 & 42 \\
\hline Control & 24 & 13 & 1 & 74 & 15 \\
\hline Total & 80 & 45 & 6 & 198 & 57 \\
\hline
\end{tabular}

Table 7. Genotype analysis of SNP 4 in case and control samples.

\begin{tabular}{|c|c|c|c|c|c|}
\hline & \multicolumn{3}{|c|}{ Genotype Count } & \multicolumn{2}{|c|}{ Allele Count } \\
\hline SNP 4/rs4904210 & CC & CG & GG & C & G \\
\hline Maxillary Canine Impaction & 24 & 42 & 17 & 90 & 76 \\
\hline Control & 9 & 20 & 9 & 38 & 38 \\
\hline Total & 33 & 62 & 26 & 128 & 114 \\
\hline
\end{tabular}

Table 8. Statistical analysis of associations between SNP and maxillary canine impaction.

\begin{tabular}{|c|c|c|c|c|c|c|c|c|c|}
\hline \multirow[t]{2}{*}{ Gene } & SNP & HWE & & $\begin{array}{l}\text { Genotype } \\
\text { Count }\end{array}$ & & $\begin{array}{c}\text { Genotype } \\
\text { p-value }\end{array}$ & $\begin{array}{l}\text { Allele } \\
\text { Count }\end{array}$ & & $\begin{array}{c}\text { Allele } \\
\text { p-value }\end{array}$ \\
\hline & $\begin{array}{c}\text { SNP } \\
3 / \\
\text { rs12881240 }\end{array}$ & 1 & $\mathrm{CC}$ & CT & TT & & C & $\mathbf{T}$ & \\
\hline \multirow[t]{4}{*}{ PAX9 } & Case & & 46 & 32 & 5 & 0.5831 & 124 & 42 & 0.3447 \\
\hline & Control & & 24 & 13 & 1 & & 61 & 15 & \\
\hline & OR $(95 \% \mathrm{Cl})$ & & 1 & $1.28(0.57-2,89)$ & $2.61(0.29-23.61$ & & 1 & $1.38(0.71-2.68)$ & \\
\hline & $\begin{array}{c}\text { SNP } \\
4 / \mathrm{rS} 4904210\end{array}$ & 0.856 & $\mathrm{CC}$ & CG & GG & & C & G & \\
\hline \multirow[t]{3}{*}{ PAX9 } & Case & & 24 & 42 & 17 & 0.814 & 90 & 76 & 0.5427 \\
\hline & Control & & 9 & 20 & 9 & & 38 & 38 & \\
\hline & OR $(95 \% \mathrm{Cl})$ & & 1 & $0.79(0.31-2.00)$ & $0.71(0.23-2.16)$ & & 1 & $0.84(0.48-1.45)$ & \\
\hline
\end{tabular}

Chi-square test $p<0,05$ ( Sig 2- Tailed ), HWE: Hardy-Weinberg equilibrium 


\section{Table 9. Associations between gender and SNP frequency.}

\begin{tabular}{|c|c|c|c|c|c|c|c|c|c|}
\hline & & \multicolumn{3}{|c|}{ SNP $3 /$ rs 12881240} & \multirow[b]{2}{*}{$\begin{array}{c}\text { P- } \\
\text { Value }\end{array}$} & \multicolumn{3}{|c|}{ SNP 4 / rs4904210 } & \multirow[b]{2}{*}{$\begin{array}{c}\text { P- } \\
\text { Value }\end{array}$} \\
\hline & & $\begin{array}{c}C C \\
(n=70)\end{array}$ & $\begin{array}{c}\text { CT } \\
(n=45)\end{array}$ & $\underset{\substack{\text { TT } \\
(n=6)}}{ }$ & & $\begin{array}{c}\text { CC } \\
(n=33)\end{array}$ & $\begin{array}{c}C G \\
(n=62)\end{array}$ & $\begin{array}{c}G G \\
(n=26)\end{array}$ & \\
\hline CASE & C Impaction & 46 & 32 & 5 & 0.5831 & 24 & 42 & 17 & 0.814 \\
\hline & Control & 24 & 13 & 1 & & 9 & 20 & 9 & \\
\hline & OR $(95 \% \mathrm{Cl})$ & 1 & $\begin{array}{c}1.28 \\
(0.57-2.89)\end{array}$ & $\begin{array}{c}2.61 \\
(0.29-23.61)\end{array}$ & & 1 & $\begin{array}{c}0.79 \\
(0.31-2.00)\end{array}$ & $\begin{array}{c}0.71 \\
(0.23-2.16)\end{array}$ & \\
\hline SEX & Male & 28 & 21 & 4 & 0.3996 & 14 & 26 & 13 & 0.7725 \\
\hline & Female & 42 & 24 & 2 & & 19 & 36 & 13 & \\
\hline & OR (95\% Cl) & 1 & $\begin{array}{c}0.76 \\
(0.36-1.62)\end{array}$ & $\begin{array}{c}0.33 \\
(0.06-1.94)\end{array}$ & & 1 & $\begin{array}{c}1.02 \\
(0.43-2.40)\end{array}$ & $\begin{array}{c}0.74 \\
(0.26-2.07)\end{array}$ & \\
\hline
\end{tabular}

Chi-square test $p<0,05$ ( Sig 2- Tailed)

Although the frequency of genotype variation was higher in females than in males, the difference was not statistically significant $(P=0.7725)$. Consequently, these findings suggested that gender was not a major influence on the occurrence of maxillary canine impaction.

\section{Discussion}

The etiology of canine impaction might be multifactorial and involve external factors, such as environmental input (e.g., trauma), local factors (e.g., lack of space, prolonged retention of primary teeth, trauma to permanent tooth seeds, rotation of permanent seed teeth, and the presence of pathological lesions, such as dentigerous cysts or odontoma), genetic factors, and systemic disease ${ }^{18-24}$. Dentistry is increasingly making use of genetic information, which plays an important role in addressing clinical problems, especially with regard to dental abnormalities or anomalies, including impaction of the maxillary canines. Previous studies show that tooth development is regulated by $>200$ genes $^{23}$. PAX9 encodes a transcription factor and is among the most frequently identified genes affecting the odontogenic process and involved in the occurrence of dental anomalies, such as agenesis teeth, congenital missing teeth, and variabilities in tooth size and position. The identification of genetic risk factors associated with canine impaction has recently become the subject of intensive research.

In this study, DNA sequencing of 121 of 132 patient and control samples identified four SNPs located in a similar region of PAX9 exon 3 (Table 2). SNPs play a role in determining disease characteristics, including etiology and the incidence and risk of disease development. Subsequent analysis revealed that all of the identified SNPs would result in missense mutations (Table 3). These findings suggest that SNPs might be efficacious for determining dental anomalies, specifically the impaction of maxillary canines.

Although we found no statistically significant association between $P A X 9$ genotype and maxillary canine impaction
(Table 8), there were variations between patients with and without this condition according to the presence of SNP 3 and SNP 4, which carried a greater risk for maxillary canine impaction. A previous study reported that the genes involved in the impaction or displacement of canines into the palate are also responsible for controlling the growth and eruption of teeth ${ }^{25}$, and Klein et al. ${ }^{26}$ showed that dental anomalies (size, shape, and position of teeth and agenesis of teeth or supernumerary teeth) were determined by a set of genes involved in tooth development. The results of the present study suggested a potential role for $P A X 9$ in tooth growth and development.

In summary, our findings showed no statistically significant association between SNP genotype and gender and demonstrated that although the frequency of impaction-related genotype variation in women was higher than that in men, the differences were not statistically significant. These results suggested that gender-associated variations in genetic profile do not contribute to the incidence of maxillary canine impaction.

\section{Consent}

Written informed consent for publication of patient details was obtained.

\section{Data availability}

Underlying data

ABI files and chromatograms that support the findings of this study are available on reasonable request from the corresponding author [author initials] and by submitting the applicable request form ('Form Padia' to request access for genetic resources (available as part of the OSF deposit)). The data are not publicly available due to them containing information that could compromise research participant privacy.

Open Science Framework: Genotyping Analysis Pax9 Gene In Patients With Maxillary Canine Impaction. https://doi.org/ 10.17605/OSF.IO/B37CJ ${ }^{17}$. 
This project contains the following underlying data:

\section{- ELECTROPHORESIS_RESULTS- PAX9 GENE.docx_ 05-02-2018 (Gel images)}
- RAW DATA _F1000 Vitria E 05-02-2019L.xlsx (Patient data)

\section{Extended data}

Open Science Framework: Genotyping Analysis Pax9 Gene In Patients With Maxillary Canine Impaction. https://doi. org/10.17605/OSF.IO/B37CJ ${ }^{17}$

This project contains the following extended data:

- PADIA form-Pax0 gene_Vitria E-05-02-2019.docx (Data access form)
Data are available under CCO 1.0 Universal Public Domain Dedication

\section{Grant information}

The author(s) declared that no grants were involved in supporting this work.

\section{Acknowledgements}

We are grateful for the editage for their copyediting services. We also thank you to Dr. Miesje Karmiati who helped establish the clinical diagnosis of canine tooth impaction cases in this study. Lastly, we thank Astridevitanti (Vivi) who helped work on PCR in Oral Biology Laboratory, Faculty of Dentistry UI.
1. Power SM, Short MB: An investigation into the response of palatally displaced canines to the removal of deciduous canines and an assessment of factors contributing to favourable eruption. Br J Orthod. 1993; 20(3): 215-22. PubMed Abstract | Publisher Full Text

2. Dachi SF, Howell FV: A survey of $\mathbf{3 , 8 7 4}$ routine full-mouth radiographs. I. A study of retained roots and teeth. Oral Surg Oral Med Oral Pathol. 1961; 14: 1165-9.

PubMed Abstract | Publisher Full Text

3. Thilander B, Myrberg N: The prevalence of malocclusion in Swedish schoolchildren. Scand J Dent Res. 1973; 81(1): 12-20. PubMed Abstract | Publisher Full Text

4. Wang $\mathrm{Y}, \mathrm{Wu} \mathrm{H}, \mathrm{Wu} \mathrm{J}$, et al:: Identification and functional analysis of two novel PAX9 mutations. Cells Tissues Organs. 2009; 189(1-4): 80-7. PubMed Abstract | Publisher Full Text | Free Full Text

5. Das $P$, Stockton DW, Bauer $C$, et al:: Haploinsufficiency of PAX9 is associated with autosomal dominant hypodontia. Hum Genet. 2002; 110(4): 371-6. PubMed Abstract | Publisher Full Text

6. Kapadia H, Frazier-Bowers S, Ogawa T, et al.: Molecular characterization of a novel PAX9 missense mutation causing posterior tooth agenesis. Eur J Hum Genet. 2006; 14(4): 403-9. PubMed Abstract | Publisher Full Text

7. Pereira TV, Salzano FM, Mostowska A, et al.: Natural selection and molecular evolution in primate PAX9 gene, a major determinant of tooth development. Proc Natl Acad Sci U S A. 2006; 103(15): 5676-81. PubMed Abstract | Publisher Full Text | Free Full Text

8. Kapadia H, Mues G, D'Souza R: Genes affecting tooth morphogenesis. Orthod Craniofac Res. 2007; 10(4): 255-44. PubMed Abstract | Publisher Full Tex

9. Mercuri LG, O'Neill R: Multiple impacted and supernumerary teeth in sisters. Oral Surg Oral Med Oral Pathol. 1980; 50(3): 293. PubMed Abstract | Publisher Full Text

10. Peck S, Peck L, Kataja M: The palatally displaced canine as a dental anomaly of genetic origin. Angle Orthod. 1994; 64(4): 249-56. PubMed Abstract

11. Peck S, Peck L, Kataja M: Prevalence of tooth agenesis and peg-shaped maxillary lateral incisor associated with palatally displaced canine (PDC) anomaly. Am J Orthod Dentofacial Orthop. 1996; 110(4): 441-3. PubMed Abstract | Publisher Full Text

12. Pirinen $S$, Arte $S$, Apajalahti $S$ : Palatal displacement of canine is genetic and related to congenital absence of teeth. J Dent Res. 1996; 75(10): 1742-6. PubMed Abstract | Publisher Full Text

13. Peck S, Peck L: Palatal displacement of canine is genetic and related to congenital absence of teeth. J Dent Res. 1997; 76(3): 728-9. PubMed Abstract | Publisher Full Text

14. Peck S, Peck L, Hirsh G: Mandibular lateral incisor-canine transposition in monozygotic twins. ASDC J Dent Child. 1997; 64(6): 409-13. PubMed Abstract

15. Peck S, Peck L, Kataja M: Mandibular lateral incisor-canine transposition, concomitant dental anomalies, and genetic control. Angle Orthod. 1998; 68(5): 455-66. PubMed Abstract

16. Neubüser A, Koseki H, Balling R: Characterization and developmental expression of PAX9, a paired-box-containing gene related to PAX1. Dev Biol. 1995; 170(2): 701-16.

PubMed Abstract | Publisher Full Text

17. Bachtiar EW: Genotyping Analysis Pax 9 Gene In Patients With Maxillary Canine Impaction. 2019. http://www.doi.org/10.17605/OSF.IO/B37CJ

18. Litsas G, Acar A: A review of early displaced maxillary canines: Etiology, diagnosis and interceptive treatment. Open Dent J. 2011; 5: 39-47. PubMed Abstract | Publisher Full Text | Free Full Text

19. Bishara SE: Impacted maxillary canines: A review. Am J Orthod Dentofacial Orthop. 1992; 101(2): 159-71.

PubMed Abstract | Publisher Full Text

20. Thilander B, Jakobsson SO: Local factors in impaction of maxillary canines. Acta Odontol Scand. 1968; 26(2): 145-68. PubMed Abstract | Publisher Full Text

21. Schindel RH, Duffy SL: Maxillary transverse discrepancies and potentially impacted maxillary canines in mixed-dentition patients. Angle Orthod. 2007; 77(3): 430-5.

PubMed Abstract | Publisher Full Text

22. Richardson G, Russell KA: A review of impacted permanent maxillary cuspids-diagnosis and prevention. J Can Dent Assoc. 2000; 66(9): 497-501. PubMed Abstract

23. Becker A, Sharibi S, Chaushu S: Maxillary tooth size variation in dentitions with palatal canine displacement. Eur J Orthod. 2002; 24(3): 313-8. PubMed Abstract | Publisher Full Text

24. Peck S, Peck L, Kataja M: The palatally displaced canine as a dental anomaly of genetic origin. Angle Orthod. 1994; 64(4): 249-56. PubMed Abstract

25. NIH US National Library: What are single nucleotide polymorphisms (SNPs)? 2019. Reference Source

26. Klein ML, Nieminen P, Lammi L, et al:: Novel mutation of the initiation codon of PAX9 causes oligodontia J Dent Res. 2005; 84(1): 43-7. PubMed Abstract | Publisher Full Text 


\section{Open Peer Review}

\section{Current Peer Review Status:}

\section{Version 1}

Reviewer Report 26 April 2019

https://doi.org/10.5256/f1000research.18746.r47551

(C) 2019 Razak F. This is an open access peer review report distributed under the terms of the Creative Commons Attribution License, which permits unrestricted use, distribution, and reproduction in any medium, provided the original work is properly cited.

\section{Fathilah Binti Abdul Razak}

Department of Oral and Craniofacial Sciences, University of Malaya, Kuala Lumpur, Malaysia

The attempt to associate paired-box gene 9 (PAX9) mutation to tooth impaction in patients was interesting and the decision to target on the occurrence of maxillary canine impaction was logical and appropriate. The study design was clearly outlined, well described and detailed. Data obtained was adequate, which enabled derivation of meaningful outcomes. The authors were able to demonstrate that the presence of SNPs 3 and 4 is actually associated with the increased likelihood of suffering from maxillary canine impaction. This finding definitely adds valuable information to the current knowledge.

In general, this is a nicely written manuscript. The flow of ideas and thoughts of the authors throughout the manuscript were effectively presented, focused and of high quality.

Is the work clearly and accurately presented and does it cite the current literature? Yes

Is the study design appropriate and is the work technically sound?

Yes

Are sufficient details of methods and analysis provided to allow replication by others? Yes

If applicable, is the statistical analysis and its interpretation appropriate? Yes

Are all the source data underlying the results available to ensure full reproducibility? Yes

Are the conclusions drawn adequately supported by the results? Yes 
Competing Interests: No competing interests were disclosed.

Reviewer Expertise: Oral Biology

I confirm that I have read this submission and believe that I have an appropriate level of expertise to confirm that it is of an acceptable scientific standard.

Reviewer Report 22 March 2019

https://doi.org/10.5256/f1000research.18746.r45394

(C) 2019 Susilowati $\mathbf{H}$. This is an open access peer review report distributed under the terms of the Creative Commons Attribution License, which permits unrestricted use, distribution, and reproduction in any medium, provided the original work is properly cited.

\section{Heni Susilowati}

Department of Oral Biology, Faculty of Dentistry, Gadjah Mada University, Yogyakarta, Indonesia

This study has reported new information that is very important to explain the effect of genes mutation in canine impaction. This research is very interesting. The researcher analysed the relationship between mutations and Pax9 gene polymorphisms with cases of canine tooth impaction. This research has been carried out using gene sequencing. The results showed an association between Pax9 gene mutations (SNPs 3 and 4) with the appearance of maxillary canine teeth impaction.

The abstract contains concise and clear information about the background, objectives, methods, results and conclusions, so that it is quite easy for the readers.

The following are inputs to improve the quality of this manuscript:

1. In the abstract, it is written in the background section: "Paired-box gene 9 (PAX9) mutation is often associated with impaction in some patient populations." This indicates that previous researchers may have conducted similar studies in different populations. It is advisable to write about this in the introduction, to strengthen the reasons for choosing the pax 9 gene and also in the discussion, to analyse possible similarities or differences in pax 9 polymorphism in different study populations.

2. The results showed that gender has no effect on the incidence of canine impaction, genderassociated genetic variation has no contribution. It would be better if the authors explain the possible causes, or show references from previous research reports that are relevant to the phenomenon. Does this occur only in canine impaction or is it possible for other tooth impaction cases?

3. Please add to the discussion section, factors that are likely to cause the emergence of Pax 9 gene polymorphism.

4. Material and methods: the researcher conducted a sequencing analysis, please explain whether the method used is next generation sequencing.

Is the work clearly and accurately presented and does it cite the current literature? Yes

Is the study design appropriate and is the work technically sound? 
Yes

Are sufficient details of methods and analysis provided to allow replication by others? Yes

If applicable, is the statistical analysis and its interpretation appropriate?

Yes

Are all the source data underlying the results available to ensure full reproducibility? Yes

Are the conclusions drawn adequately supported by the results? Yes

Competing Interests: No competing interests were disclosed.

Reviewer Expertise: Cell Biology

I confirm that I have read this submission and believe that I have an appropriate level of expertise to confirm that it is of an acceptable scientific standard.

The benefits of publishing with F1000Research:

- Your article is published within days, with no editorial bias

- You can publish traditional articles, null/negative results, case reports, data notes and more

- The peer review process is transparent and collaborative

- Your article is indexed in PubMed after passing peer review

- Dedicated customer support at every stage

For pre-submission enquiries, contact research@f1000.com 